УДК 821.163.41.09"18” Караџић, В. С. https://doi.org/10.18485/msc50.2019.1.ch10

Димитрије Вученов

\title{
ВУКОВО ПРИСУСТВО У СРПСКОЈ РЕАЛИСТИЧКОЈ ПРОЗИ
}

Вук и његово дело имају толико широке и многе димензије да је и тема о којој бих хтео да говорим - иако би по својој природи требало да буде релативно ограничена - толико обимна да ју је немогућно исцрпсти и потпуно представити и у много шире заснованом излагању него што ће бити ово моје. Зато ће бити неопходно да се оно ограничи на неке општије тезе. Срећна је околност што су теме излагања колега проф. Новаковића и проф. Живковића из овог или блиског круга питања, па ће оне, уз то са̂ме много конкретније него што је ова, дати потребну рељефност питањима којих се ја више могу дотаћи него их развити у обиму који по своме значају заслужују.

Остајући, дакле, у сфери општег, пошао бих од основног питања: какав је могао бити удео Вуков у епохи реализма у српској књижевности, кад је на њеним почецима, а и током њеног трајања, био тако снажно присутан идејни утицај покрета Светозара Марковића и јављања првих социјалистичких идеја и погледа на друштво међу Србима. Да ли су Вуков и Марковићев утицај на епоху српског реализма међусобно опречни, противречни, или су они текли један поред другог не супротстављајући се један другоме? Или су, можда, - ако јесу, како и у којој мери - били комплементарни?

Пре покушаја да се одговори на ово питање треба поставити питање и о једном, не баш ретком схватању у историји књижевности, које се заснива на тези да се књижевне епохе смењују у токовима књижевног развитка тако да нова епоха представља негацију старе, претходне епохе у целини или у већем делу онога што чини суштину, што чини бит те претходне епохе; да се приликом смене оспоравају вредности које је претходна епоха афирмисала. На ово је требало указати с обзиром да ће овде бити речи о могућности да једна значајна компонента претходне епохе, романтизма, траје и током нове књижевне епохе, реализма. 
Одмах се може рећи да ова теза не би могла важити за све ситуације и све случајеве, тј. за токове развитка сваке књижевности и у сваком времену, јер развитак културе, па дакле и књижевности, тече веома сложено. Треба имати на уму да развитак књижевности у разним срединама нема исти ток и ритам. Посебно треба нагласити да је било народа чија је историја била таква да су, хтели они то или не, морали у свом културном развитку заостати за народима који су се развијали у повољнијим условима. У културама таквих народа, па, разуме се, и у књижевностима њиховим, нужно долази до сустизања више епоха, до њиховог прожимања и преплитања у различитим особинама и односима. Тада се јавља много сложеније питање односа између појединих епоха у тој књижевности, па и тешкоће у периодизацији којом се хоће што јасније временски разлучити једна епоха од друге с циљем да се доследно примени европска књижевна периодизација.

То је свакако случај и са српском књижевношћу у XIX столећу, са њеном периодизацијом. Скерлић је морао да прибегне и тако недовољно дефинисаним називима као што је назив Од рационализма ка романтизму. За тај период он ће у својој Историји нове српске кюижевности (Београд, 1914, стр. 134) рећи: „Одлика овог периода, који иде од прилике од 1810. до пред 1848. годину, то је прелазност”. Ако, пак, погледамо које књижевне ствараоце ставља овај наш историчар књижевности у овај период говорећи о сваком од њих и посебно, онда ћемо наћи посебне одељке о овим писцима: Лукијан Мушицки, Јоаким Вујић, Милован Видаковић, Михајло Витковић, Димитрије Давидовић, Ђорђе Магарашевић, Теодор Павловић, Сима Милутиновић Сарајлија, Јован Стерија Поповић, Петар Петровић Његош, Јован Стејић, Јован Хаџић (Милош Светић), Ђорђе Малетић, Јован Суботић, Никанор Грујић, Васа Живковић, Матија Бан, Медо Пуцић, Данило Медаковић, Љубомир Ненадовић, Милица Стојадиновић Српкиња.

Скерлић је, очигледно, наишао на период у којем су се стекле разне књижевне епохе и правци, па је решење тражио у дефинисању овог периода као прелазног. Он јесте прелазан, али се у њему сустижу неколико књижевних праваца и струја. Познавање дела наведених књижевних стваралаца јасно указује на то да они не могу припадати једној књижевној школи која би обележила епоху. Сам Стерија је посебан проблем у овом периоду због полифоничности свога књижевног стварања, јер он припада неколиким књижевним правцима и школама, па је класичан пример сустизања и престизања књижевних епоха у делу једног писца.

Књижевну епоху треба ипак ставити у некакав временски период, у некакве, бар приближне, временске границе. И Скерлић је за почетак 
ове епохе узео годину 1810, док јој је крај означио мало неодређеније: „до пред 1848. годину”. То може да значи и 1847. и 1846. па, можда, и 1845. годину. Но ми сви знамо како је тешко један књижевни период временски тачно одредити, па зато и не бисмо смели у том погледу бити превише оштри у својој критици Скерлићевог одређивања трајања овог периода. Ипак треба указати на понешто што се измиче оваквој периодизацији Скерлићевој. Укажимо на то да је, ако наше познавање настанка појединих дела није погрешно, Ђорђе Малетић ипак написао знатно више после 1848. године него пре тога. А то се односи, опет ако се не варамо, и на Јована Суботића, Никанора Грујића, Васу Живковића, Матију Бана, Меду Пуцића, Данила Медаковића, Љубомира Ненадовића и Милицу Стојадиновић Српкињу. А то је скоро половина књижевних стваралаца која би својим делима требало да представљају овај период од 1810. до пред 1848. годину. И не само то, него размислимо да ли је уопште могућно Љубомира Ненадовића и Милицу Стојадиновић Српкињу и ставити као књижевне ствараоце у тај период. Љубомир Ненадовић рођен је 1826. и 1846. године имао је двадесет година. Милица Стојадиновић Српкиња рођена је 1830. и 1846. имала је шеснаест година. Како онда може њихово књижевно стварање спадати у период од 1810. до пред 1848. годину?

С друге стране, Вук Караџић, који је стављен у епоху романтизма, и те како је много већ био створио пре 1848. Постало је већ опште место у нашим историјама књижевности и у књижевноисторијским расправама како је 1847. године врхунац његовог деловања, којим се обележава његова коначна победа после двадесет и пет година борбе.

Па и у нешто каснијем времену наилазимо на питања и проблеме сличног карактера. По чему и у чему је, на пример, Змајева сатирична поезија романтична? Или његова дечја поезија? А сатирична и дечја поезија чине, ипак, знатан део Змајевог поетског стварања. По чему и у чему су, даље, сатиричне приповетке Ђуре Јакшића романтичне?

Оваквих и сличних питања могло би се, разуме се, поставити још доста. Но то и није задатак овог излагања. Задовољимо се само указивањем на то да оваква питања постоје. У тешкоће и недоследности морао је због тога упасти и тако значајан историчар књижевности као што је био Јован Скерлић. И то, пре свега, због објективних разлога. Хтео је једну од европских периодизација књижевности применити на развитак српске књижевности у XIX столећу, а тај развитак му је добрим делом измицао због таквог поступка, јер су се у том развитку српске књижевности сустизале епохе, напоредо се јављали књижевни правци и школе; а он је то због периодизације настојао да занемари. 
Пошто смо наше питање ставили у шири контекст развитка српске књижевности, вратимо се њему и поставимо питање негирања и оповргавања поетике романтизма од стране нове епохе, реализма у смислу познате тезе да нова епоха у књижевности настаје и уобличава се супротстављањем претходној. Запитајмо се да ли то, пре свега, бива увек и у свим елементима? Ако је реч о поетици српског романтизма, запитајмо се, даље, да ли је она истоветна са поетиком европског романтизма? Ове две поетике свакако су имале штошта заједничко, али знак једнакости између њих се ипак не би могао ставити. Не бисмо овде улазили даље у то питање, него ћемо се опет задовољити само тиме да и на њега укажемо. За нас је много значајније то што добар део Вуковог доприноса поетици српског романтизма није био негиран од стране епохе реализма. Разлози су свакако вишестрани и сложени. Може се поставити претпоставка и да је та поетика била шира од романтичне или да није доследно романтична, а можда би се могла изнети још која претпоставка. Но било која од могућих претпоставки да буде постављена, и после истраживања или анализа потврђена, остаће чињеница да је не само знатан део Вукове поетике био прихваћен од стране епохе реализма у српској књижевности него и да је знатан део Вукове визије српске културе остао вредност и за наредну епоху, да се уградио у њу и у њој био делотворан, но, разуме се, никако не и једини.

Епоха реализма у српској књижевности, наиме, не само што се временски подудара са јављањем првог социјалистичког покрета код Срба него се значајно прожимала с њим. Први заступници и заговорници реалистичког правца у књижевности код нас јавили су се у публицистици социјалистичког покрета Светозара Марковића. Заступајући у својим погледима на друштво социјалистичке идеје, припадници покрета Светозара Марковића постављали су у исто време и захтеве за реализмом у књижевности. Оваква повезаност друштвених и књижевних погледа имала је, и морала је имати, и одређене последице.

Прихватајући и бранећи тезу да нација није монолитан организам у којем као да нема конфронтације између његових делова, социјалисти су морали оспорити романтични и романтичарски однос према нацији. А пошто су се у српској средини прожимали погледи социјалиста у друштвеном и реалиста у књижевном животу, онда је то постало и идејно опредељење ових књижевних стваралаца. Они су морали изразити друштвене супротности у самој нацији и у име осећања друштвене правде бити на страни угроженог дела друштва. А стварно, у тадашњој друштвеној ситуацији и односима, угрожени део друштва у Србији било је сељаштво. 
Но пре него што развијемо ову мисао даље, треба скренути пажњу на судбину социјалистичких идеја у Србији. Социјалистичке идеје првог друштвеног покрета такве оријентације у српском друштвено-политичком животу јавиле су се прво из додира српске студентске омладине на студијама у иностранству са социјалистичким идејама у Русији, Француској и са оном мешавином од демократских, републиканских, па до социјалистичких али и утопистичких, па чак и анархистичких идеја у тадашњој Швајцарској, пуној емиграната свих могућих политичких оријентација и боја. Због тога те социјалистичке идеје у свести првих српских присталица социјализма нису могле бити уобличене у јединствен, у кохерентан идејни систем. Зато у њима има и недоследности и противречности, и зрелих идеја и утопистичких. Једном речју, има и доста тога што се не уклапа у научни социјализам, у марксизам.

Међутим, идеологије се не могу просто пренети из једне друштвене средине, из једне одређене друштвене и историјске ситуације у другу која није у свему истоветна; при преношењу оне морају пустити корене у домаћем тлу, морају наћи одговарајуће услове у домаћим приликама, у конкретним социјалним условима, у домаћој клими тог друштвеног поднебља. А ти услови у Србији морали су бити посебни, јер је она тада била неразвијена аграрна, дакле сељачка земља тек недавно ослобођена од туђинског, уз то примитивног феудализма.

Једно од значајних дела Светозара Марковића, а вероватно и најзначајније, Србија на Истоку, било је у ствари већим својим делом социјална историја српског села у XIX столећу и, онолико колико је требало за основну ауторову тезу, социјална историја српског села и српског сељаштва више столећа пре тога. Србија на Истоку је стваран аналитички продор у друштвену ситуацију српског села у Марковићевој савремености и релативно дугој прошлости која јој је претходила. Тим делом је Светозар Марковић у извесном смислу наставио или, боље речено, допунио дело Вука Краџића. Ако је, наиме, Вук открио и представио српску рустичну културу као основну и битну вредност српског друштва на којој ће се моћи даље развијати култура општијег карактера, Светозар Марковић је анализом показао социјални положај тога основног извора на којем је Вук замислио и засновао даљи српски културни развитак. То је био разлог и један од услова да се „сретну” Вук и Марковић у осмишљавању епохе реализма у српској књижевности, да њихова дела и утицај њихове мисли буду међу конституентима ове књижевне епохе.

Немајући у својој домаћој средини индустријског пролетеријата, први српски социјалисти, а пре свега Светозар Марковић, јавили су се као браниоци села и сељака и давали су анализе из којих се видела социјал- 
на угроженост сељаштва и примитивна и сурова њихова експлоатација. Немајући стварне услове да у тадашњој Србији, у духу социјалистичких идеја, постави у средиште друштвенополитичке борбе ра дн и ч ко питање, први социјалистички покрет у Срба поставио је сељачко питање. А тражећи од књижевности да слика савремени живот и социјалне односе, они су тиме упутили српску реалистичку прозу ка темама из сеоског живота, ка темама о сељачким животним ситуацијама и судбинама. Веома је карактеристично што се у Раду, првом социјалистичком књижевном и научном часопису (ако не узмемо у обзир Преоднииу, први социјалистички лист београдских великошколаца) у првој фази његовог излажења, дакле године 1873/74, као једини белетристички прилог у сва 34. односно свих 36. бројева, налази превод француског романа ЕркманШатријана под, за наше виђење веома илустративним насловом Историја једног франиуског сељака. Већ у избору романа под овим и оваквим насловом може се назрети нека врста акцента у тематској оријентацији, која се и тиме указује српским писцима од стране присталица Светозара Марковића и његовог покрета.

Опредељујући се у том правцу, писци реалисти су се ангажовали у одбрани села и сељаштва. Опредељујући се, међутим, у том правцу, они нису могли мимоићи и захват у сеоску свест, а она је оним што је у њој било културно и друштвено вредно већ била великим делом репрезентована, представљајући у ономе што највећим делом чини Вуков корпус.

Окретањем ка селу, српски реализам је омогућио даље широко присуство Вуково у тој епоси. Слика села у књижевном стваралаштву српског реализма није била само вуковска, али је била и вуковска. А да она буде и таква, поред поменутих друштвених и идејних разлога, постојали су и други.

Већина српских реалиста потицала је са села, у којем је провела своје детињство и живела ту у атмосфери усмене народне књижевности, у клими усмене народне песме и приче и проверене вредности афоризма што се у нас зове пословица, у поднебљу једне не школске него животне филозофије која у својој емпиријској основи није била препрека и визијама света које дочарава машта. Па чак и кад не потичу са села, као Матавуљ, на пример, они су у најужој, породичној средини окружени усменим причањем и усменим причаоцима. Познато је, а вредно је поменути поновно, како је усмено причање Матавуљеве мајке привлачило у њихов дом у Шибенику знатан број слушалаца, као и Матавуљево сведочење о томе да су му као потка за неке његове приповетке послужили причања његове мајке не само у дому него и кад би се с њом возио колима на вашаре. Баба Бојану, у вези са Јанком Веселиновићем не треба ни 
помињати посебно, као ни Домановићеву мајку и друге. Но ако не треба посебно помињати сва ова појединачна сведочења о значају усмене народне књижевности за формирање свести будућих приповедача, треба поновно скренути пажњу на једну чињеницу која повезује вуковски удео у српској култури са епохом реализма у српској књижевности, а то је да су скоро сви српски реалисти били талентовани усмени приповедачи. И Глишић, и Веселиновић (који је уз то био и певач уз гусле), и Лазаревић, и Матавуљ, и Сремац, и Домановић и Нушић били су целог свог живота козери и усмени приповедачи, људи живе и богате усмене речи, која је причаноме давала одмах форму приповетке, причане, разуме се, са упадицама онако слично као што је, на свој начин то представљено у Кочићевим приповеткама о Симеуну Ђаку. Ако томе додамо још и то да су ти писци, и кад су се настанили у Београду, били опет у једној средини у којој су се усмена прича и усмено причање, у атмосфери тадашње београдске боемије, ценили више од написане приповетке, онда смо тиме донекле заокруглили слику општије условљености која се стекла у епоси реализма да се и психологијом стваралаца њихово дело повезује са вуковским концептом културе; не у свему, али ипак у много чему.

Прва два разлога допуњују се и трећим. Наиме, ако теоријска полазна платформа епохе реализма није била довољно богата разрађенијом естетичком теоријом (а није била), она се у пракси стваралаштва ипак морала ослонити на нешто што је било стваралачко искуство, па онда то, снагом индивидуалног талента, дати на одређеном нивоу уметничке нарације. Од композиционих ембриона падају нарочито у очи анегдота, шаљива народна прича, тежња ка бајци, прекорачивање границе између реално вероватног и фантастичног као остатка митског начина мишљења, и још понешто. С тим у вези треба такође указати и на то да је и лирика тога времена - мислим на дескриптивну лирику, лирику пејзажа у поезији Војислава Илића - везана за сеоски пејзаж иако је сам песник дете града.

У склопу онога што је из Вукове културне и књижевне ризнице својим присуством сведочило о присуству Вука и његовог корпуса у епоси реализма, јесте и оснажена вредност говорног језика и његовог односа према књижевном. Тај однос Вуков, мислим на теоријски однос у најширем обиму, подударао се са захтевом реализма да се што верније слика живот, дакле и говор као једна од његових манифестација. То што се ту иде до дијалекатског, до регионалног и локалног, уклапа се потпуно у општу концепцију Вукову да се књижевни језик формира из говорног. Што се ту у појединостима јављају несугласности између Вука и реалиста, не бих сматрао битним, нити бих улазио у разуђеније расправљање 
о томе овом приликом. Уосталом, зашто би и морали погледи његови и њихови у свему да се подударају, слажу.

Моја је теза да је Вук својим делом остао присутан и у епоси реализма низом елемената свога концепта културе и културних вредности, али не и да се између њега и епохе реализма може ставити знак једнакости. Величина Вукова није могла бити у томе да покрије и прекрије сва будућа времена, него у томе да буде присутан у њима својим погледима на којима се заснива даљи развитак у новим условима и на новим ступњевима културног раста.

Говор, језик, књижевни израз, то није само оно што се може ставити у књигу што се зове речник по неком реду, азбучном, абецедном или алфабетском, него је у њему снага човекова да искаже њиме своје виђење света око себе у многоликим односима, било већ постојећим, било могућим, било визионарским, итд. Такво једно богатство пружало је Вуково дело српским реалистима са могућностима да му додају свој обол, да новим спрегама и односима обогате не само до тада постигнуте употребе односа речи него и да остваре још многе нове могућности.

И кад бисмо се зауставили на овим видовима Вуковог присуства у епоси реализма, било би то довољно. Међутим, ни ту није граница његовог присуства. Али, ово излагање нема задатак да исцрпе тему него само да назначи репарне тачке. А оне су у томе:

- $\quad$ да је епоха реализма преузела, прихватила, примила као своје оне културне и књижевне вредности које је као такве означио и Вук: тако је епоха реализма потврдила Вукову визију културе;

- $\quad$ разлози за овакав однос у епоси реализма према Вуку били су сличности друштвених погледа или у њиховој делимичној подударности у виђењу села, сељака и вредности у сељачкој средини, али и у психологији, менталитету стваралаца реалиста. 